\title{
Investigation of Hypothetico-Creative Reasoning Skills of Teacher Trainees in Terms of Their Thinking Styles
}

\author{
İsmail Gelen \\ Ondokuz Mayıs University, Turkey \\ Volkan Duran \\ Gazi University, Turkey \\ Bayram Ozer \\ Ondokuz Mayıs University,Turkey
}

\section{Introduction}

Style is a very broad term and adjective notion used in literature as in many forms in relation with cognitive, learning, teaching, thinking, conceptual, tempo, modus vivendi, decision-making and problem-solving styles as well as mind styles, perceptual styles and intellectual styles. Many researches were conducted to distinguish styles from abilities and personality (Zhang, Sternberg, Rayner, 2002:3-4, Nielsen,2002: 21-23). Furthermore styles are relatively flexible and adaptive reactions to content-specific, contextual, dynamic situations (Duran, 2014) and it is difficult to merge all those different styles in a coherent picture. Styles are more automatic than strategies which are more optional in this sense (Cassidiy,2004: 421). Generally, style can be defined as the stable and habitual preferences of individuals manifesting themselves in various ways such activities, behaviors, attitudes.Style can be defined as the unique and habitual way of individuals' information processing about handling and interpretation of data and information in many respects such as problem solving, thinking, perceiving and remembering in the context of intelligence, personality and ability. Learning and teaching styles can be defined as a preferred strategy of an individual to teach and to learn (Nielsen,2002: 24, Sternberg \& Zhang, 2001). "Intellectual styles," can be defined as an umbrella concept regarding all style constructs referring to people's partly fixed, relatively stable and innate preferences about information processing and handling with the tasks that they may confront (Zhang \& Sternberg, 2005). Construct in there indicates a specific measurable factor that can be collected under a domain 
(Rayner, Rodenburg,Rodenburg: 2002:51).In this sense the domain of intellectual styles encompass cognitive, affective, physiological, psychological, and sociological dimensions of human intellect (Zhang \& Sternberg, 2005: 2). The concepts of holist-analytic and verbal-imagery are the key dimensions of cognitive styles. Meaning-reproduction or deepsurfaceperspective on learning and studying are the affective dimensions of intellectual styles. Being visual, aural, read/write, and kinesthetic in learning preferences can be regarded as the physiological and biological dimensions of intellectual styles. Introversion-extroversion in learning preferences are among the psychological more restrictly cognitive and affective dimensions of intellectual styles. Structured-unstructured or internal- external regulation in learning preferences are regarded among the social dimension of the domain of intellectual styles (Cassidy, 2003:68-69).
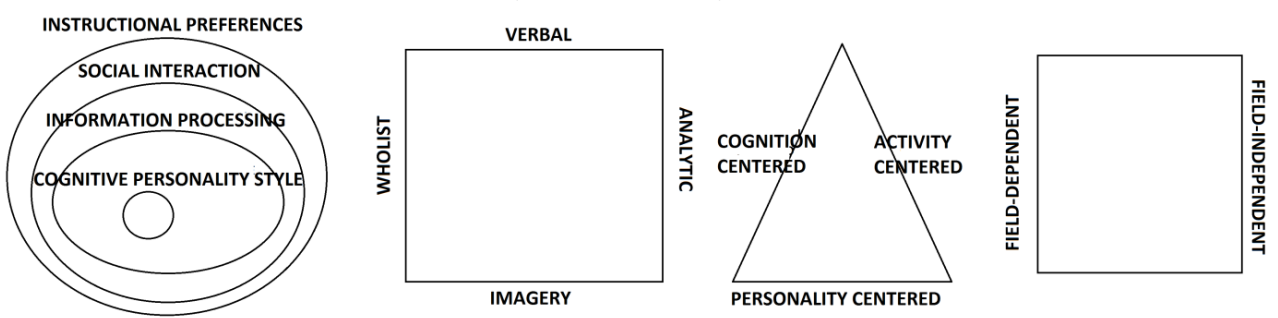

Figure 1. Classification of Styles. Curry's “onion" model (left); Riding and Cheema's model (middle left) Riding and Rayner's model (middle right), Witkin's fielddependent/field-independent learning style (right).

Curry's "onion" model; Riding and Cheema's Fundamental Dimensions; Riding and Rayner's Cognitive-Centered, Learning-Centered, and Personality-Centered approaches; and Zhang and Sternberg's Threefold Model of Intellectual Styles can be regarded among the unifying frameworks the concept of the "style".Curry's "onion" model can be regarded as the first metaphorical model for the classification of styles in this regard. The innermost layer of the onion is related with personality dimensions, the middle layer is related with the constructs regarding information processing and the outermost layer is related with individuals' instructional preferences.Learning behaviors are deeply affected and manipulated by the structure of personality and manifested in the middle layers and outer layes in the information processing with regard to social interaction and instructional preferences. The first layer is instructional preference level including concepts such as preferences of learning environment, perceptual mode, time of day, design of the physical environment. The second layer is social interactionlevel along the dimensions independent/ dependent, collaborative/competitive, and participant/avoidant.Information processing style is presented as the third 
layer of style. The fourth layer of style is cognitive personality style, which encompasses relatively stable personality dimensions.(Cassidy, 2003:6971;Zhang, Sternberg, Rayner, 2002:10). According to Witkin (1973) learning styles are concerned with the forms as processes rather than the contents of the learning activity. Hence learning styles can be categorized in terms of two dimensions as field-dependent and field-independent. Fielddependent learners focus on wholes (forest) and they are holistic whereas field-independet learners seek the details (tree in the forest) and they are detail oriented.Riding and Cheema (1991) classified styles as along two primary cognitive-style dimensions: wholist-analytic and verbalimagery.The first one is related with the tendencies about processing information as parts or wholes. The second one is related with preferences to represent information verbally or in terms of mental pictures. Sternberg and Grigorenko's $(1997,2001)$ categorized style theories into cognitioncentered, activity-centered, and personality-centered style theories.

Kolb's classification of learning styles based on two dialectically related modes of grasping experience-Concrete Experience (CE) and Abstract Conceptualization (AC)-and two dialectically related modes of transforming experience- Reflective Observation (RO) and Active Experimentation (AE).The dominant combination of those experiencing, reflecting, thinking, and acting manifest themselves as $\mathrm{CE}, \mathrm{AC}, \mathrm{RO}$ and $\mathrm{AE}$. Concrete experiences appear through the sensory cortex, reflective observation involves the integrative cortex at the back, creating new abstract concepts occurs in the frontal integrative cortex, and active testing involves the motor brain in Kolb's model (Kolb and Kolb, 2005:2).It should be noted that Kolb takes the fundemental dimensions of his learning styles based on the regions of brain in relation with each dimensions (Figure 2. Right) but those dimensions can be classified in terms of the dominant characteristics of right and left brain hemispheres (Figure 2 left).

Similarly Gregorc (1979) established his model of learning styles based on four observable behaviours as abstract, concrete, random and sequantial and identified learning styles based on the combination of those four dimensions. Concrete sequantial learners are more prone to learn directly, sensory-based and step by step instruction and information, concrete random learners are more likely to engage in the instruction based on intuition, trial and error, independent approaches. Abstract sequantial learners are more inclined to learn logical, analytical rule based information and abstract random learners have holistic, visual, experiantial, unstructured learning preferences (Figure 3 left) (Cassidy,2004:429). 

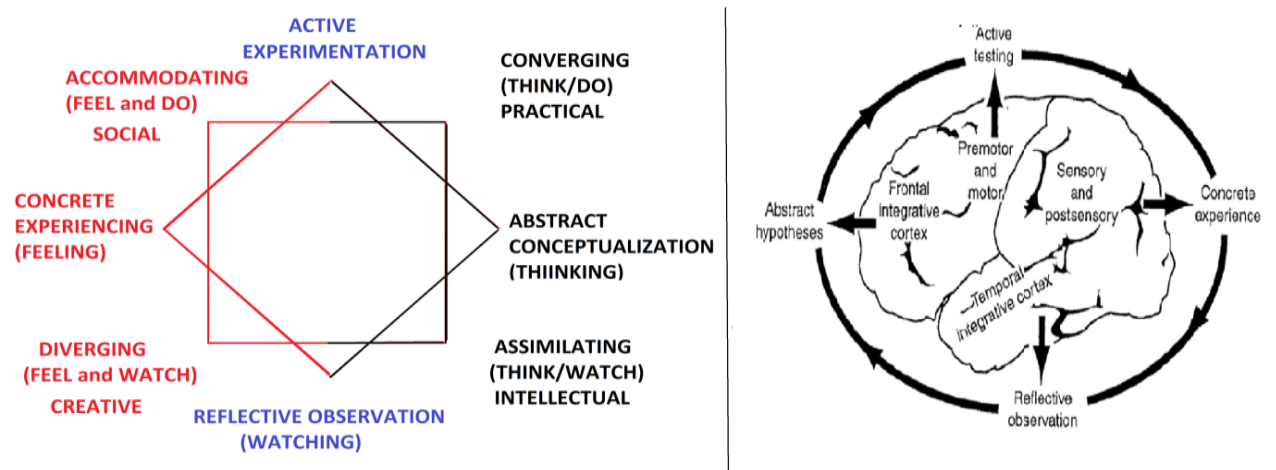

Figure 2. Kolb's classification of learning styles in terms of the characteristic of of hemispheric specialization of the brainand the brain regions in relation with experiencing, reflecting, thinking, and acting (Zull,2002).

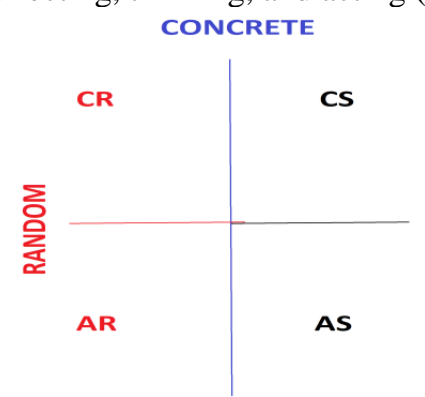

ABSTRACT

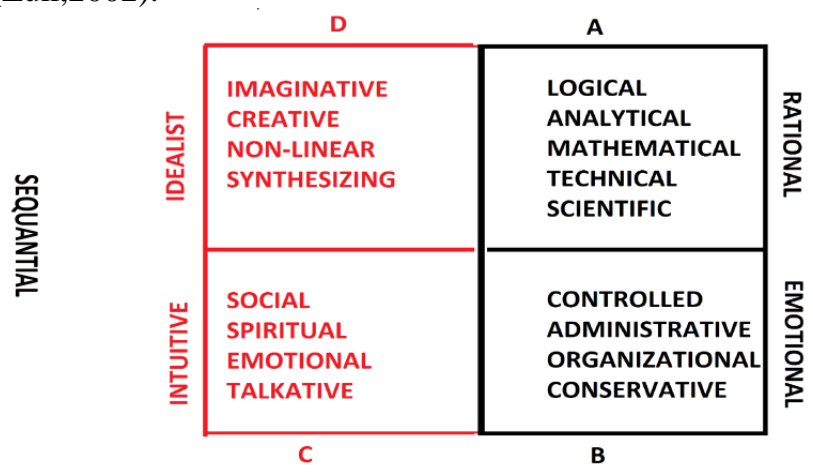

Figure 3. Gregorc thinking styles (middle) can be conceived in terms of hemispheric specialization of the brain: The general chracteristics of right brain (left) and left brain (right) (Blue color indicates that those concept can be belonged to both sides)

Accorrding to Herrmann's metaphorical model of brain dominance, the dominancy of A-quadrant (left cerebral mode) is in relation with the activities involving logical, analytical and factual information in the context of the ability to perceive, verbalise and express information. B-quadrant (left limbic mode) iindicates similarities to an A-quadrant thinking but A quadrant is rational whereas $\mathrm{B}$ quadrant emotional and it is inclined to activites as organised, sequential, planned and detailed information and conservative in their actions. The $\mathrm{C}$-quadrant (right limbic mode) process the information which is interpersonal, including feelings and is also kinaesthetic. D quadrant (right cerebral mode) is mainly characterised by a holistic approach (Figure 3 right) (Hermann, 2003:27-77). 


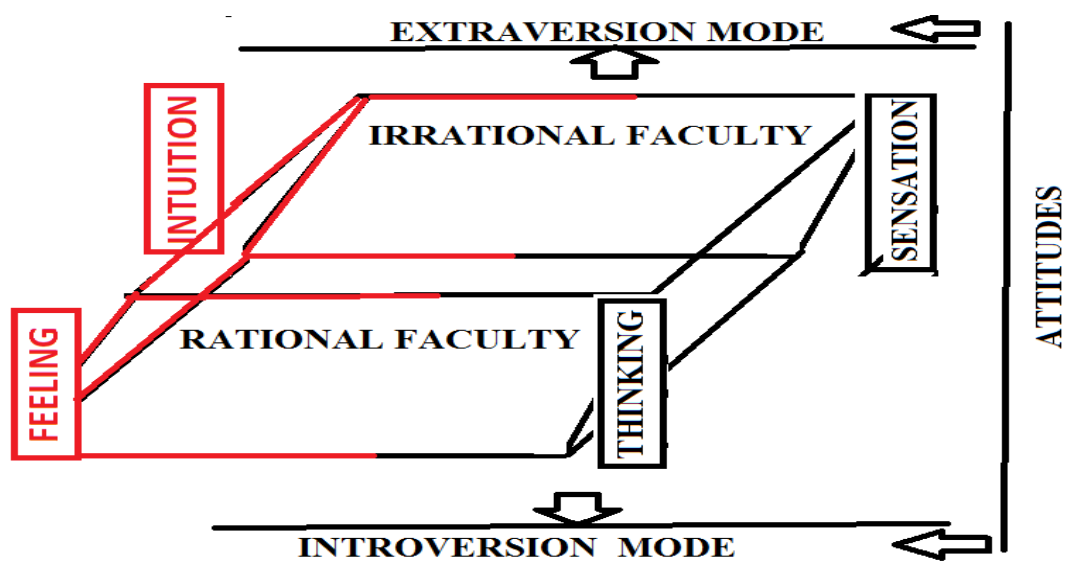

Figure 4. Jung's personality model can be conceived in terms of hemispheric specialization of the brain. (Duran,2015).

Jungs personality modes also based on thinking (frontal left), sensing (back left), intuition (frontal right), feeling (back right) which can be conceived as similar with Herrmann's model (Figure 4) (Sharp,1984:14; Fordham, 2001: 35-55).The roots of Hermann's model can be found the neurophysiological research of Sperry and Gazzaniga on split-brained patients, and is eloboratted by Ornstein (1977).The theory proposed the idea that the two halves of the brain engage in the information processes in adversely opposite ways. Left hemisphere is generally more specialized for language performance and proceed informationpart by part in a sequential manner. However, the right hemisphere is usually more specialized for visual-spatial and mathematical tasks and process any informaton hollisticaly. According to West (1997), there are links between a particular earning style and an individual's tendency to favor a particular hemisphere when processing information. The left hemisphere is related with the verbal, analytical, abstract, temporal, and digital style (the auditory learners) whereas the right hemisphere the nonverbal, holistic, concrete, spatial, creative, and intuitive style (the visual learners). The concept of different brain functioning is said to be supported by brainimaging techniques (Chan, 2002:378, Sousa, 2003, 2006, 2007, Ornstein, 1977; Sperry, 1968). Hence there are differences and dissimilarities in the anatomy and functions of right and left cerebral hemispheres. The right hemisphere separates itself from the left hemisphere in terms of the dominant characteristics such as being holistic, visual, inductive that is more creative and more dominant in the expression of emotions. However left hemisphere is more deductive, logical, analytic, verbal in this regard. The localization or dominance of a function on one side of the brain in preference to the other side is defined as lateralization (Yöney,2001).The localization may occur because of many intrinsic and 
extrinsic factors but it doesn't mean that all people have a dominant preferences for the lateralization.

It can be seen that many learning styles can be classified as wholist-anaytic style family such as Witkin'sField-Dependence/Field Independence, Kagan's Impulsivity Reflectivity, Convergent-Divergnet Styles,Holzman and Klein's Leveller-Sharpener Styles,Pask's Holist-Serialist Style, Kaufmann's Assimilator-Explorer Style, Allinson and Hayes' IntuitionAnalysis Style, Gregorc's learning styles (Cassidy,2004:425-440) and even Kolb's Learning Styles as seen Figure 2, Figure 3 and Figüre 4. Indeed there are other learning styles such as Pavio's Verbalizer-Visualizer Cognitive Style, Vermunt's learning styles inventory, Bigg's Study Process Model (Cassidy,2004: 425-440), those are all thought to be categorized the dominated characteristics and dimensions of the brain halves.

Sternberg (1988) introduced of the theory of mental self-government, where intellectual styles specify 13 thinking styles that fall along five dimensions of mental self-government: (a) functions, (b) forms, (c) levels, (d) scopes, and (e) leanings of government as applied to individuals (Zhang, Sternberg, Rayner, 2002: 14).

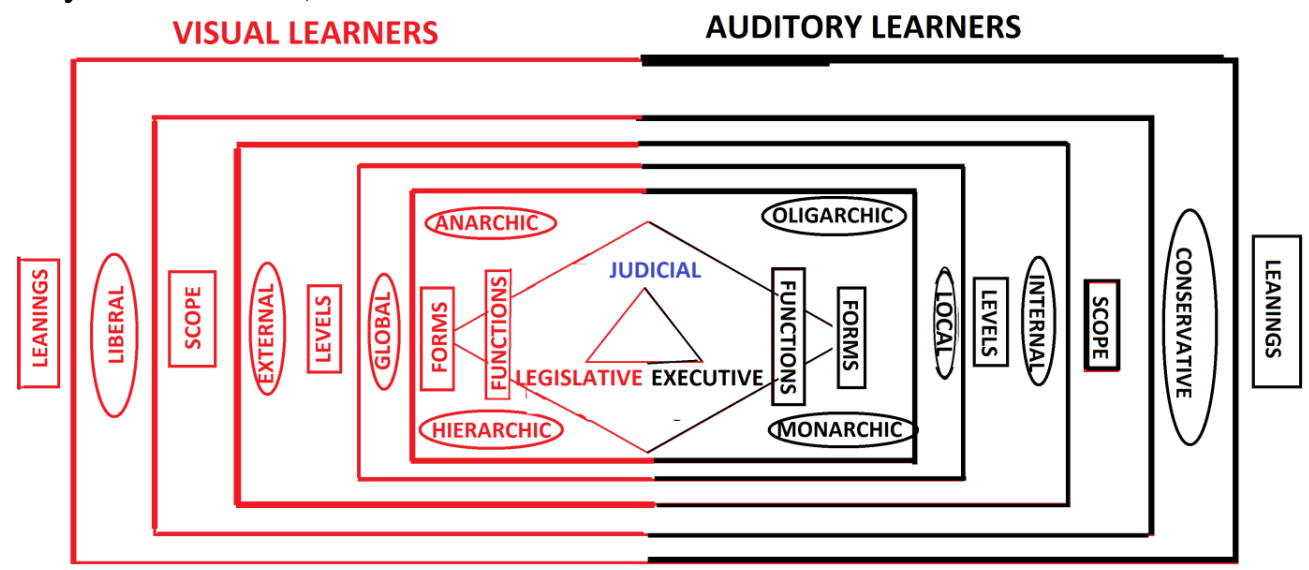

Figure 5. Intellectual styles in terms of the theory of mental self-government, it can be conceived in terms of hemispheric specialization of the brain.

His theory based on the principle that people "organize or govern themselves" in ways corresponding to the kinds of governments that exist world-wide" (Sternberg, 1999: 148).According to Zhang and Sternberg (2005) intellectual styles have threefold structure in which Type I styles are more inclined to be creativity generating and in relation withlow-structure tasks denoting higher levels of cognitive complexity, Type II styles have norm-favoring tendency and are related with structured tasks denotingmore straightforward information processingand finally Type III styles may display the features of either Type I or Type II styles, depending on the 
demands of the specific task, content and context. In this paper the thinking styles are represented as Figure 5 in accordance with the dominant characteristics of left brain (black region) and right brain (red region).

Nevertheless, taxonomy based on brain dominance model can be criticized because we only have "two pigeonholes" and we arrange so many attributes into these two categories. Also some researches suggest that individuals use both halves of brain interactively in Daily events. However it can be regarded that the brain dominance model is a useful coherent tool to understand all of these styles (Chan, 2002: 379).

Styles can be conceived the disposition of the characteristics of left and right brain combining with the cognitive history and temperament, personality, attitudes of individuals when they confronted with a stimulus. They are less stable than temperament, personality, attitudes and more stable than cogntive strategies. In this regard they depend much on metacognitive skills rather than conditioned learned behaviours which have a much deeper cognitive history however cognitive strategies may have more degree of freedom than the intellectual styles. Information processing is mostly related with the fucntion of left brain and experiantial learning is mostly related with right brain altought those two brain can function all of them and also complement each other. In this regard the dispositional way of styles can be depicted as Figure 5 in this sense (Schleifer \& Dull, 2009, SaddlerSmith,2002:166-167, Furnham, 2002: 175-177).According to the findings of Rosencwajg and Corroyer (2005) reflective individuals who implemented analytical processing and metacognition are cognitively mature, whereas impulsive individuals who used holistic processing were cognitively immature and in this regard the hierarchyof Figure 5 can be depicted based on the usage of metacognition and conditioning. Similar results in terms of reflexivity was found by Nietfeld and Bosma (2003) and in terms of the self-directed learning behaviors of adult third-languageLearners by Rivers (2001) (Figure 5).

Creativity is an ability to ask unusual questions and to ask new connotations and solutions. Creative people are not satisfied what they have, they pursue a vision and act as an entrepreneur and follow his/her dream for a some sort of mystical transcended goal passing beyond the present time and space (Gardener, 1993;Gelen,2014:121). According to Csiksizentmihalyi creativity has three domains as individualistic, cultural and social (Gardner, 2007: 80).Human cognition is also affected by those three domains as well as environmental factors and the content and context of information. Hence right and left distinction is not enough to explain the individual differences without including those domains. Zhang and Sternberg (2002: 132-149) 
made the hypothetical distinction between right and left brain the context of Hofstede's Cultural Dimensions which consist of dimensions low power distance, LPD; low uncertainty avoidance, LUA; individualism, I; and masculinity, $\mathrm{M}$ and higher power distance, HPD; high uncertainty avoidance, HUA; collectivism, C; and femininity, F. For example assertiveness and decisiveness are more valued in masculine societies whereas rule-following and obedience are much more appreciated in feminine societies. In cognitive terms, people from masculine cultures are more prone to be engaged in new ways of thinking, whereas people from feminine cultures are more likely to be engaged in more conventional thinking. In this category the left-right brain distinction is implicitly made in the context of intellectual styles which is similar to the distinction in this paper.

Zhang (2002) pointed out that the right and left brain distinction in the context of thinking modes. Information is processedin a piecemeal, analytical, and sequential manner in analytic mode of thinking (left-brained dominance) process whereas information is mostly processed in an intuitive, gestalt-type, synthesised manner in holistic mode of thinking (originally right-brained dominance). Information is processed information in an interactive and dynamic way in an integrative mode of thinking (originally whole-brained dominance) (Zhang, 2002:394).

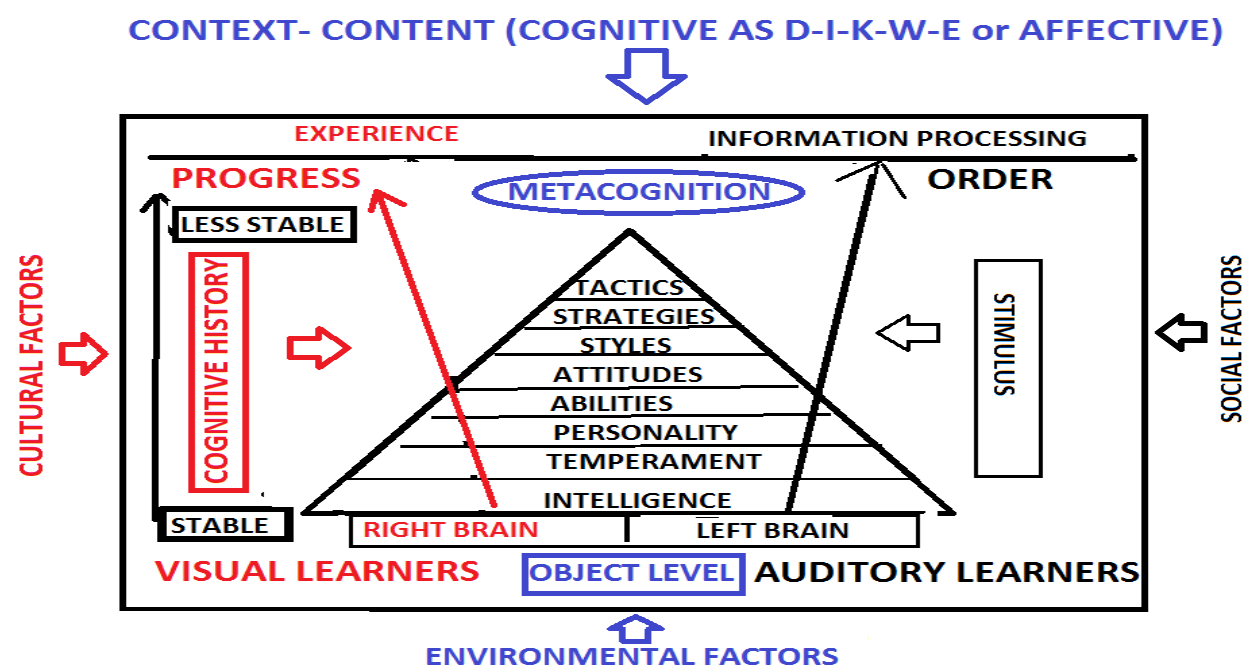

Figure 6. Styles can be conceived the disposition of the characteristics of of hemispheric specialization of the brain combining with the cognitive history and temperament, personality, attitudes of individuals when they confronted with a stimulus (Duran,2015). 
It should be noted that left-right brain distinction is just a conceptual and theoretical model in order to better understand the cognitive concepts. Human cognition is so complicated and is affected in many ways ranging from nutrion to education to socio-cultural-economic factors. It is also affected by age, gender, the stages of human development, role models, social status and class, politics, the developmental stage of the country people live in etc. Hence the vectoral summation of the sub-dimension of those factors with respect to factors mentioned above may chaotically so developed thatthe sub-dimensional chracteristics of brain-halves become superior which are contrary to the characteristics of "dominant brain halve" in which individuals generally developed (Figure 6). The one of the reason why we can see so many people having so different and rich differences and attributes maybe resulted from complicated vector network of human society. Furthermore, we as humans are not deterministic machines and our behaviours maybe based on some contexual decision makings hence more elastic than the models depict. Finally some people may also use their brains cooperatively without any specific dominance and this can be reflected in their styles .

Hypothetico-Creative reasoning model developed by Duran (2014) based on six inner dimension of Lawson's hypothetico-predicitive and six outer dimension of creative thinking skills found in the literature. Hypotheticopredicitive reasoning skills are hypothetic reasoning, proportional reasoning, controlling variables, probabilistic reasoning, correlational reasoning and combinational reasoning (Lawson, 1995: 61-62). Six outer dimensions of creative thinking skills are analogical thinking, convergent thinking, divergent thinking, metaphorical thinking,vertical thinking and lateral thinking. Data is processed through data-information-knowledge-episteme conversion and extraction processes in order to construct epistemological beliefs as ideas and opnions in hypothetico-creative model along with the the process of affective information in the hierarchy of needs, drives, motives, incentives, intention (commitment/perseverance), passion and finally eros (Duran, 2014: 91-92, Duran,2015). Hence hypothetico-creative model can be conceived as an integrative mode of thinking and reasoning (originally whole-brained dominance) including both logical and creative sides of human brain. 


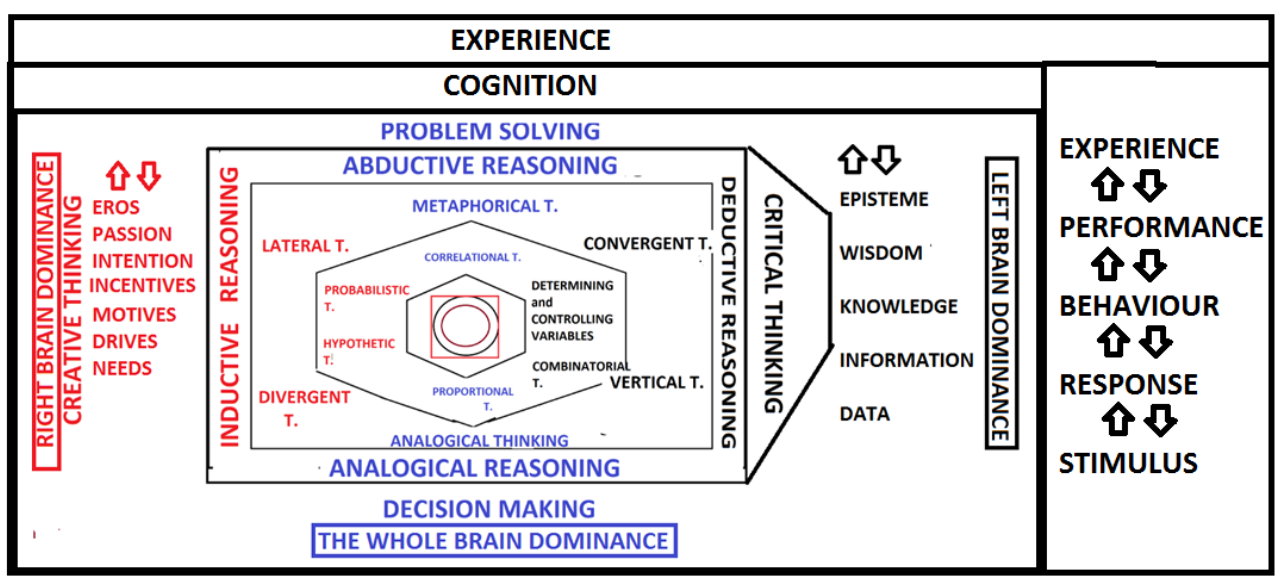

Figure 7. Hypothetico-Creative Model (Duran,2014,2015,2016) and hypothesized classicification based on the hemispheric specialization of the brain.

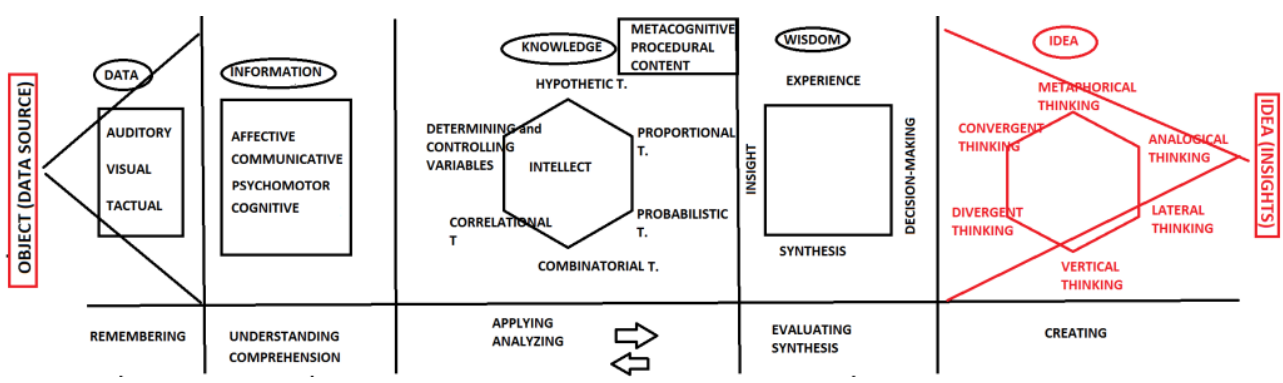

Figure 8. According to Hypothetico-Creative Model data is processes in both lineer and non-lineer ways into information, knowledge, wisdom and ideas and their correspondance in Bloom's taxonomy (modified from Duran,2014 and 2015)

In this regard hypothetico-creative reasoning skills can be classified based on the characteristics of left and right hemisphere as seen by Figure 7 . In the theoretical investgation of literature research both learning styles and thinking skills can be categorized in terms of the dominant characteristics of brain hemipheres. It is thought that hypothetico-creativity should encapsulate integrative mode of thinking. Problem solving and decision making is thought to be both belonged to right and left hemispheres. For example problems can be solved both creatively and deductively. Hence blue color indicates that those concept can be belonged to both sides.

To sum up, Hypothetico-creative model includes both cogntive and behaviorist theories based on Bloom's taxonomy in this regard. In this model, data as auditory, visual and tactual forms of knowledge unit can be converted into bigger and meaninful clusters which is called as information corresponding to comprehension level in Bloom's taxonomy. Information can be classified as affective, communicative, psychomotor and cognitive in this model. Knowledge is created from information through the faculties of 
hypothetico-deductive thinking skills as hypothetic thinking, proportional thinking, probabilistic thinking, combinatorial thinking, correlational thinking, determining and controlling variables. Knowledge can be classified as content, procedural and metacogntive in this model. As said by Hegel, the action of separating the elements is the exercise of the force of understanding. Similarly Sizek pointed out that understanding is understood as the elementary form of analyzing, of fixing differences and identities in that sense (Sizek,2012: 275-276). In this regard knowledge is the form of information processed through the dimensions of logical thinking skills. Wisdom in this regard is defined as the ability to discern or make decisions about what is true, right based on insight, knowledge and it corresponds the sub-level in Bloom's revised taxonomy . Finally ideas (episteme) corresponds to the extended abstract level where individuals makes connections (Figure 8). Furthermore, cognitive characteristics of the brain is metaphorically classified as creative and logical par tor left and right brain distinction and the behavioral chracteristics of human experiences are shaped in the context of stimulus, response, behaviour, performance and experience distintion. It is thought that there is a hierarchy both in cognitive and behavioral dimensions (Figure 7). However this hiearachy is proposed as a map to understand the levels or processes in learning and this map is not a strict map that every individual must follow those steps in every kind of learning situation. Sometimes previous experiences, learnings may help individuals to transform or block their previous knowledge into the new one. Other complex factors from environment, culture, society may also contribute to individuals to process data and information non-lineer and chaotic ways. (Duran,2014;2015;2016). To sum up, hypothetico-creative model can be understood as a map depicting thinking and reasoning skills based on the information units in accordance with the Bloom's taxonomy and Lawson (1995)'s hypothetico-deductive thinking skills.

\section{Purpose}

The purpose of this study is to investigate the relationship between learning styles proposed by Sternberg (1988) and hypothetico-creative reasoning skills proposed by Duran (2014) in the context of the characteristics of left an right brains and the empirical research done so far. In this regard the main questions of this research can be given as

Question 1: What is the relationship between the dimension of functions of learning styles (perception of their learning styles) and hypotheticocreative reasoning skills

(perception of their reasoning skills)? 
Question 2: What is the relationship between the dimension of forms of learning styles (perception of their learning styles) and hypotheticocreative reasoning skills (perception of their reasoning skills)?

Question 3: What is the relationship between the dimension of levels of learning styles (perception of their learning styles) and hypotheticocreative reasoning skills (perception of their reasoning skills)?

Question 4: What is the relationship between the dimension of scopes of learning styles (perception of their learning styles) and hypotheticocreative reasoning skills

(perception of their reasoning skills)?

Question 5: What is the relationship between the dimension of leanings of learning styles (perception of their learning styles) and hypotheticocreative reasoning skills

(perception of their reasoning skills)?

\section{Method}

This study is a descriptive study based on, relational screening model among the screening models. The relational screening model is performed to determine the relationship between two or more variables and obtain clues in the context of cause and effect relationship. The design of this research is conducted by correlational research design $\mathrm{s}$ a quantitative method of research in which the main aim is to determin whether there is a relationship (or covariation) between the 2 variables or more (Büyüköztürk, Çakmak, Akgün, Karadeniz and Demirel,2008). Hence the variables of this study consist of the hypothetico-creative reasoning skills inventory and thnking styles.

\section{Population}

In this study firstly departments were chosen through simple random sampling among the 21 different deparmtents. Then, English Teaching Department, Preschool Education Department,Department of Elementary Education, The Department of Computer Education and Instruction, The Department of Psychological Counseling And Guidance were selected. In the second phase, the purposive sampling technique was used and all the second grade students $(\mathrm{N}=383)$ in those departments in the education period 2015-2016 were seleected.

\section{Limitations}

This study is limited with the teacher candidates in the sample, hyptheticocreative reasoning skills inventory, intellectual styles (learning styles) inventory. 


\section{Data Collection and Analysis}

Two inventories are used for data collection

1. Thinking Styles Inventory: First measurement tool is the "The Thinking Style Inventory-TSI" developed by Stemberg (1992) and translated and adopted to Turkish language by Fer (2005). Fer (2005) found that pearson product moment correlation coefficients between the Turkish and English versions of the inventory ranged from, 0.40 to 0.99 . by disregarding the items 4 and 73, indicating that inventory has an acceptable reliability. All the correlation coefficients were significant at 0.01 level. In this context pearson correlation coefficients of styles is found to be legislative 0.78 , executive 0.95 , judicial 0.83 , monarchici 0.83 , hierarchic 0.94 , oligarchic 0.93, anarchic 0.93, global 0.95, local 0.88, internal 0.88, external 0.80, liberal 0.92 , external 0.54 which indicated acceptable reliability.Positive and siginificant values found in all sub-scales $(\mathrm{p}=0.00$ ve 0.01 ). The average of correlation coefficient of all sub-scales is 0.79 . items. The total internal consistency of the scale's items was 0.89 . Hence the scale is translated and adopted in Turkish with additional analysis (Fer, 2005:43). As seen table both

$\alpha_{1}$ values for original 104 items of the translated inventory, $\alpha_{2}$ values 70 items for the adapted inventory $r_{1}, r_{2}, r_{3}$ values are given below Table 1 .

\begin{tabular}{|c|c|c|c|c|c|c|}
\hline Subscales & $\begin{array}{l}\text { Item Number ( } 70 \\
\text { Items of DBE) }\end{array}$ & $\alpha 1$ & $\alpha 2$ & r1 & R2 & r3 \\
\hline Legistlative & $1,2,3$ & .65 & .70 & $.54-.66$ & $.76-.80$ & .74 \\
\hline Executive & $10,12,13,14$ & .58 & .75 & $.42-.65$ & $.71-.82$ & .72 \\
\hline Judicial & $\begin{array}{l}18,19,21,22,23, \\
53,54,74\end{array}$ & .58 & .78 & $.40-.65$ & $.52-.72$ & .74 \\
\hline Monarchic & $6,15,32,38,39$ & .50 & .62 & $.35-.57$ & $.55-.73$ & .68 \\
\hline Hierarchic & $11,33,34,35,37$ & .82 & .81 & $.59-.79$ & $.66-.85$ & .74 \\
\hline Oligarchic & $41,43,46,48,49,72$ & .67 & .68 & $.47-.67$ & $.37-.76$ & .63 \\
\hline Anarchic & $50,51,52$ & .71 & .70 & $.41-.70$ & $.76-.81$ & .75 \\
\hline Global & $26,57,58,61,63,64$ & .77 & .81 & $.48-.78$ & $.62-.75$ & .75 \\
\hline Local & $69,70,71$ & .71 & .76 & $.40-.75$ & $.76-.88$ & .71 \\
\hline Internal & $4,5,8,75,77,78,79,80$ & .81 & .81 & $.54-.73$ & $.54-.76$ & .73 \\
\hline External & $83,84,85,86,87,88$ & .82 & .89 & $.40-.84$ & $.72-.84$ & .78 \\
\hline Liberal & $81,89,90,91,93,94,95$ & .75 & .85 & $.51-.78$ & $.53-.82$ & .71 \\
\hline Conservative & $97,98,101,102,103,104$ & .89 & .90 & $.49-.88$ & $.61-.88$ & .72 \\
\hline
\end{tabular}

\footnotetext{
$\alpha 1$ : TSI with 104 items (Alpha)

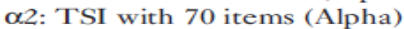

r1: TSI with 104 items (Item-total)

r2: TSI with 70 (Item-total)
}

r3: TSI with 104 items (Test-tetest)

As seen Table 13, inventory has 13 factors or dimensions. 34 items are removed from the original inventory and the inventory addressing 13 
subscales under the five dimensional constructs with 70 items, is created. As seen table the lowest Cronbach alpha coefficient belongs to legislative and anarchic styles with .70 Cronbach Alpha values. Altough these values are low for the reliability analysis it can be accepted. The lowest correlation value is .72 in the latest form of the inventory with 70 items. The correlation value is more higher in other factors. Hence this inventory is thought to be reliable in this regard.

Tablo 2: The results of reliability analysis for thinking styles inventory in this study.

\begin{tabular}{|c|c|c|c|c|}
\hline \multicolumn{5}{|c|}{ Thinking Styles Inventory } \\
\hline FACTORS & $\begin{array}{l}\text { Item } \\
\text { No }\end{array}$ & $\begin{array}{l}\text { Item } \\
\text { Num }\end{array}$ & $\begin{array}{l}\text { Item Numbers } \\
\text { in Total }\end{array}$ & $\begin{array}{c}\text { Cronbach's } \alpha \text { (alpha) } \\
\text { calculated in this research }\end{array}$ \\
\hline Functions & & & \multirow{4}{*}{24} & \multirow[t]{4}{*}{ ( } \\
\hline Legislative & $2-9$ & 8 & & \\
\hline Executive & $10-17$ & 8 & & \\
\hline Judicial & $18-25$ & 8 & & \\
\hline \multicolumn{3}{|l|}{ Forms } & \multirow{5}{*}{32} & \multirow{5}{*}{.82} \\
\hline Monarchic & $26-33$ & 8 & & \\
\hline Oligarchic & $34-41$ & 8 & & \\
\hline Hierarchic & $42-49$ & 8 & & \\
\hline Anarchic & $50-57$ & 8 & & \\
\hline Levels & & & \multirow{3}{*}{16} & \multirow{3}{*}{.70} \\
\hline Global & $58-65$ & 8 & & \\
\hline Local & $66-73$ & 8 & & \\
\hline \multicolumn{3}{|l|}{ Scope } & \multirow{3}{*}{16} & \multirow{3}{*}{.78} \\
\hline Internal & $74-81$ & 8 & & \\
\hline External & $82-89$ & 8 & & \\
\hline \multicolumn{3}{|l|}{ Leanings } & \multirow{3}{*}{16} & \multirow{3}{*}{.81} \\
\hline Liberal & $90-97$ & 8 & & \\
\hline Conservative & $98-105$ & 8 & & \\
\hline Total & $\begin{array}{l}\text { Likert: } \\
7\end{array}$ & 104 & 104 & .94 \\
\hline
\end{tabular}

In this research the reliability analysis was additionaly done for the inventory consists of 104 items and findings are shown in table 3 . Hence as seen the results which are compatible with the results of Fer (2005), the original inventtory translated into Turkish is thought to be suitable fort he investigation of thinking styles of prospective teachers.

1. Hypothetico-Creative Reasoning Skills Inventory: The HypotheticoCreative Reasoning Skills Inventory was developed by Duran (2014). The questionnaire of hypothetico-creative reasoning skills inventory was created based on the six dimensions of hypothetico-predictive reasoning 
skills and creative thinking skills. In the first phase of the preparation of questionnaire, three students from Counseling and Guidance department was chosen in order to check the items both grammatically and semantically. In this process, faculty members from different departments \{research assistants (3), proffesor (1), associative proffosors (2)\} also checked the general structure of the questionnaire. Then, the questionnaire consisting 83 items were conducted to the group of students (370) who are from different departments. At the end of factor analysis, the items which are lower than .35 were removed. Hence the new questionnaire which has 37 items was produced. are conducted to 228 students from different departments along with problem solving scale developed by Ge (2001) and translated in Turkish by Çoşkun (2004) for the content validity because of close relationship between problem solving skills and hypotheticocreativity. It is thought that hypothetico-creative reasoning skills inventory is related with both logical and creative thinking skills in terms of content. Finally inventory which has 23 items based on five factors and had the value of Cronbach's Alpha as .89 was produced by eliminating the questions which were lower than .35 in the sample of group consisting of 682 individuals. In the confirmatory factor analysis was done by doing required edits through using AMOS. In the DFA result, the value of $x^{\wedge} 2 / s d$ was found to be as 1,78 , the value of CFI was found to be as . 90 , the value of GFI was found to be as .87 and the value of KMSEA was found to be as .056 hereby the confirmatory factory analysis was done in the sample of groups consisting of 282 individuals and was consisted with the predicted structure of the inventory. Furthermore, the internal structure of the inventory was also be consistent with the scientific epistemological beliefs scale developed by Elder (1999) translated by Acat, Tüken and Karadağ (2010) and Lemire's (2001) Learning Style Inventory in terms of many features (Duran, 2014). As a result the hypotheticocreative reasoning skills inventory which has 23 items and is a five likert type items was developed by doing exploratory and confirmatory factor analysis. The factors of the inventory has five dimensions which is similar with the number of the dimensions of hypothetico-predictive reasoning skills as predicted. In this research the Cronbach's alpha constant was found to be .91 additionaly.

\section{Analysis}

Multiple linear regression analysis was done for the five dimensions of thinking styles inventory and hypothetico-creativity. Thinkins styles as predictor and hypothetico-creative reasoning skils as predictand are used to determine their regression level. Firstly the pearson's correlation coefficient was calculated and descriptive statistics was done. The "Enter" mode was seleected in regression analysis method and the effect of thinkins styles as predictor on hypothetico-creative reasoning skils as predictand was analyzed 
in terms of $\beta$ and $t$ values. $B$ value indicates how much 1 unit change in thinkins styles as predictor results in a change in hypothetico-creative reasoning skils as predictand. If the $t$ value has positive value and significant $(\mathrm{p} \leq .05)$; the change in predictor value results in an increase a change in predictand value. If the $t$ value has negatiive value and significant $(\mathrm{p} \leq .05)$; the change in predictor value results in an decrease a change in predictand value.

Durbin-Watson value should be between 1 and 3 in orderto detect the presence of a relationship between values in the prediction errors from a regression analysis. Additionaly, VIF value should be smaller than 10 and tolerance should be less than 0.20 or 0.10 for the analysis of linear correlation. Moreover, the $\mathrm{p}$ and $\mathrm{F}$ values are also examined from the Anova tables provided by regression analysis.

\section{Findings}

The findings are presented in accordance the main questions of this research.

Question 1: What is the relationship between the dimension of "functions" of learning styles (perception of their learning styles) and hypotheticocreative reasoning skills (perception of their reasoning skills)?

The results for Question 1 was given in table 3.

Table 3: Descriptive statistics and pearson correlation analysis for the dimension of "functions" of learning styles and hypothetico-creative reasoning skills

\begin{tabular}{|c|c|c|c|c|c|c|c|c|c|c|c|c|}
\hline & & \multirow[t]{2}{*}{$\mathbf{N}$} & \multirow[t]{2}{*}{$\mathbf{X}$} & \multirow{2}{*}{$\begin{array}{c}\text { Std.Devi } \\
\text { ation }\end{array}$} & \multicolumn{2}{|c|}{$\frac{\text { H.Y. Akıl }}{\text { Yürüitme }}$} & \multicolumn{2}{|c|}{ Legislative } & \multicolumn{2}{|c|}{$\underline{\text { Executive }}$} & \multicolumn{2}{|c|}{$\underline{\text { Judical }}$} \\
\hline & & & & & $\mathbf{R}$ & $\bar{p}$ & $\mathbf{r}$ & $\mathbf{P}$ & $\mathbf{R}$ & $\mathbf{P}$ & $\mathbf{r}$ & $\mathbf{P}$ \\
\hline \multicolumn{2}{|l|}{$\begin{array}{l}\text { H.Creative } \\
\text { Reasoning }\end{array}$} & $\begin{array}{c}38 \\
3\end{array}$ & 80,9426 & 13,65245 & - & & ,390 & 000 & ,210 &, 000 & ,395 & ,000 \\
\hline $\begin{array}{l}\text { The } \\
\text { dimension }\end{array}$ & Legislative & $\begin{array}{c}38 \\
3\end{array}$ & 45,2089 & 6,26201 & ,390 &, 000 & - & . & ,429 &, 000 &, 533 &, 000 \\
\hline $\begin{array}{l}\text { of } \\
\text { functions }\end{array}$ & Executive & $\begin{array}{c}38 \\
3\end{array}$ & 42,3525 & 7,39736 &, 210 &, 000 &, 429 &, 000 & - & . & ,312 & ,000 \\
\hline $\begin{array}{l}\text { of } \\
\text { learning } \\
\text { styles }\end{array}$ & Judical & $\begin{array}{c}38 \\
3\end{array}$ & 39,2585 & 7,62392 & ,395 &, 000 &, 533 &, 000 &, 312 &, 000 & - & \\
\hline
\end{tabular}

Durbin-Watson valuewhich is supposed to be between values 1 and 3 is found to be 1.76. From regression analysis, $F=31,954, p=.000$ values was found indicating that they have predicting features. 
Table 4: Linear regression analysis for the dimension of "functions" of learning styles and hypothetico-creative reasoning skills

\begin{tabular}{|c|c|c|c|c|c|}
\hline $\begin{array}{l}\text { Functions (Thinking } \\
\text { Styles) }\end{array}$ & B & $\begin{array}{c}\text { Standart } \\
\text { Deviation }\end{array}$ & $\boldsymbol{\beta}$ & $\mathbf{T}$ & $\mathbf{P}$ \\
\hline Sabit & $\begin{array}{c}36,95 \\
1\end{array}$ & 4,976 & - & 7,425 & ,000 \\
\hline Legislative &, 527 & , 125 & ,242 & 4,213 & ,000 \\
\hline Executive & ,047 & ,094 &, 026 &, 501 & ,617 \\
\hline Judical & ,463 & ,098 & ,258 & 4,734 &, 000 \\
\hline
\end{tabular}

As seen results inTable 6, linear regression analysis for the dimension of functions of learning styles and hypothetico-creative reasoning skills indicates that there is a significant and meeaningful level of relationship between legistative and judicial dimensions of function and hypothetico creativity $\left(\mathrm{R}=.449, \mathrm{R}^{2}=.196, \mathrm{p} \leq .01\right) . \mathrm{B}=, 527$ value for legislative style indicates the extend of the increase for hypothetico-creativity corresponding the 1 unit increase for legislative style. Similarly $B=, 463$ value for judical style indicates the extend of the increase for hypothetico-creativity corresponding the 1 unit increase for legislative style. Legislative and judical styles explain $\% 20$ of total variance. Legislative aand judical styles are thought to be stronges predictor of hypothetico-creativity, in terms of $\beta$ constant andt values. In this context, legislative and judicial learning styles are thought to be a significant and meaningful predictor for hypotheticocreative reasoning skills.

Question 2: What is the relationship between the dimension of "forms" of learning styles (perception of their learning styles) and hypothetico-creative reasoning skills (perception of their reasoning skills)?

Table 5: Descriptive statistics and pearson correlation analysis for the dimension of "forms" of learning styles and hypothetico-creative reasoning skills

\begin{tabular}{|c|c|c|c|c|c|c|c|c|c|c|c|c|c|c|}
\hline & & \multirow[t]{2}{*}{$\mathbf{N}$} & \multirow[t]{2}{*}{$\mathbf{X}$} & \multirow{2}{*}{$\begin{array}{c}\text { Std. } \\
\text { Devia } \\
\text { tion }\end{array}$} & \multicolumn{2}{|c|}{$\frac{\text { H.Creativ }}{\text { ity }}$} & \multicolumn{2}{|c|}{$\frac{\text { Monarchi }}{\underline{c}}$} & \multicolumn{2}{|c|}{$\frac{\text { Oligarchi }}{c}$} & \multicolumn{2}{|c|}{$\frac{\text { Hierarchi }}{c}$} & \multicolumn{2}{|c|}{$\frac{\text { Anarchi }}{c}$} \\
\hline & & & & & $\mathbf{R}$ & $\mathbf{P}$ & $\mathbf{R}$ & p & $\mathbf{r}$ & $\mathbf{P}$ & $\mathbf{R}$ & $\mathbf{P}$ & $\mathbf{R}$ & $\mathbf{P}$ \\
\hline & & $\begin{array}{c}38 \\
3\end{array}$ & $\begin{array}{c}80,9 \\
4\end{array}$ & 13,65 & - & - & \begin{tabular}{|c|}
13 \\
5
\end{tabular} & ,004 & \begin{tabular}{|c|}
, 31 \\
0
\end{tabular} & ,000 & $\begin{array}{c}15 \\
7\end{array}$ & 001 & ,344 & $\begin{array}{c}.00 \\
0\end{array}$ \\
\hline $\begin{array}{l}\text { The } \\
\text { dimen }\end{array}$ & $\begin{array}{c}\text { Monar } \\
c\end{array}$ & $\begin{array}{c}38 \\
3\end{array}$ & $\begin{array}{c}34,6 \\
3\end{array}$ & 6,620 & ,135 &, 004 & & & $\begin{array}{c}.34 \\
3\end{array}$ & ,000 & $\begin{array}{c}, 06 \\
9\end{array}$ & ,089 & ,136 & $\begin{array}{c}, 00 \\
4\end{array}$ \\
\hline sion & Oligarchi & 38 & 43,0 & 7,946 & ,310 &, 000 & ,34 &, 000 & - & - &, 02 & ,333 & ,267 &, 00 \\
\hline${ }_{\text {"For }}$ & Hierarchi & \begin{tabular}{|c|}
3 \\
38
\end{tabular} & $\begin{array}{c}8 \\
30,6\end{array}$ & & & & $\begin{array}{c}3 \\
.06\end{array}$ & & .02 & & & & & $\begin{array}{l}0 \\
00\end{array}$ \\
\hline$m s "$ & $c c$ & 3 & 4 & 7,94 & 157 &, 001 & 9 & ,089 & 2 & ,333 & - & - & ,480 & 100 \\
\hline
\end{tabular}




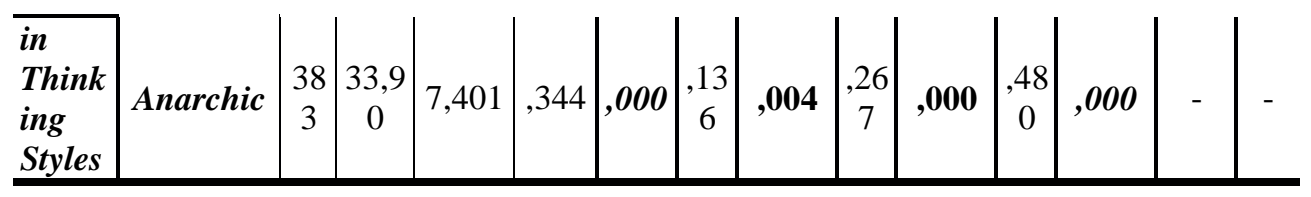

Durbin-Watsonvalue which is supposed to be between values 1 and 3 is found to be 1.79 From regression analysis, $F=19,488$, p=.000values was found indicating that they have predicting featuresAs seen results inTable 78 , linear regression analysis for the dimension of forms of learning styles and hypothetico-creative reasoning skills indicates that there is a significant and meeaningful level of relationship between anarchic and hierarchic dimensions of function and hypothetico creativity $\left(\mathrm{R}=.413, \mathrm{R}^{2}=.17, \mathrm{p} \leq .01\right)$.

Table 6: Linear regression analysis for the dimension of "forms" of learning styles and hypothetico-creative reasoning skills

\begin{tabular}{|c|c|c|c|c|c|}
\hline Variable & B & $\begin{array}{c}\text { Standart } \\
\text { Deviation }\end{array}$ & B & $\mathbf{T}$ & $\mathbf{P}$ \\
\hline Sabit & $\begin{array}{c}44,12 \\
6\end{array}$ & 4,909 & - & 8,989 & ,000 \\
\hline Monarchic &, 034 & ,103 & ,016 & ,328 & ,743 \\
\hline Oligarchic & ,404 & ,090 & ,235 & 4,497 & ,000 \\
\hline Hierarchic &, 060 & ,093 &, 035 &, 643 &, 521 \\
\hline Anarchic & , 484 & ,104 & ,263 & 4,665 &, 000 \\
\hline
\end{tabular}

$\mathrm{B}=, 484$ value for anarchic style indicates the extend of the increase for hypothetico-creativity corresponding the 1 unit increase for legislative style. Similarly $B=, 404$ value for hierarchic style indicates the extend of the increase for hypothetico-creativity corresponding the 1 unit increase for legislative style. Anarchic and hierarchic styles explain \%16 of total variance. Anarchic and hierarchic styles are thought to be stronges predictor of hypothetico-creativity, in terms of $\beta$ constant and $t$ values. In this context, anarchic and hierarchic learning styles are thought to be a significant and meaningful predictor for hypothetico-creative reasoning skills.

Question 3: What is the relationship between the dimension of "levels" of learning styles (perception of their learning styles) and hypothetico-creative reasoning skills (perception of their reasoning skills)?

Table 7: Descriptive statistics and pearson correlation analysis for the dimension of "levels" of learning styles and hypothetico-creative reasoning skills 


\begin{tabular}{|c|c|c|c|c|c|c|c|c|c|c|}
\hline & & \multirow{2}{*}{$\mathbf{N}$} & \multirow{2}{*}{$\mathbf{X}$} & \multirow{2}{*}{$\begin{array}{c}\text { Std. } \\
\text { Sapma }\end{array}$} & \multicolumn{2}{|c|}{ H. Creative } & \multicolumn{2}{|c|}{$\underline{\text { Global }}$} & \multicolumn{2}{|c|}{$\underline{\text { Local }}$} \\
\hline & & & & & $\mathbf{R}$ & $\mathbf{P}$ & $\mathbf{R}$ & $\mathbf{P}$ & $\mathbf{R}$ & $\mathbf{P}$ \\
\hline H. Creativit & & 383 & $\begin{array}{r}80,942 \\
6\end{array}$ & $\begin{array}{c}13,6524 \\
5\end{array}$ & - & - &, 141 & .003 & ,299 & .000 \\
\hline $\begin{array}{l}\text { Levels } \\
\text { dimension }\end{array}$ & Global & 383 & $\begin{array}{r}34,613 \\
6\end{array}$ & 8,02920 &, 141 & ,003 & - & - &,- 159 & .001 \\
\hline $\begin{array}{l}\text { in Thinking } \\
\text { Styles }\end{array}$ & Local & 383 & $\begin{array}{r}34,219 \\
3 \\
\end{array}$ & 8,54976 & ,299 &, 000 & $\begin{array}{c}- \\
, 159\end{array}$ & .001 & - & - \\
\hline
\end{tabular}

As seen Table 7, Durbin-Watson valuewhich is supposed to be between values 1 and 3 is found to be 1.747. From regression analysis, $F=27,309$, $\mathrm{p}=.000 \mathrm{values}$ was found indicating that they have predicting features.

Table 8: Linear regression analysis for the dimension of "levels" of learning styles and hypothetico-creative reasoning skills

\begin{tabular}{cccccc}
\hline Variable & B & $\begin{array}{c}\text { Standart } \\
\text { Deviation }\end{array}$ & B & T & P \\
\hline Constant & 51,545 & 4,251 & - & 12,124 &, 000 \\
Global &, 329 &, 083 &, 194 & 3,987 &, 000 \\
Local &, 526 &, 078 &, 329 & 6,779 &, 000 \\
\hline
\end{tabular}

As seen results inTable 8, linear regression analysis for the dimension of levels of learning styles and hypothetico-creative reasoning skills indicates that there is a significant and meeaningful level of relationship between global and local dimensions of function and hypothetico creativity $(\mathrm{R}=.355$, $\left.\mathrm{R}^{2}=.121, \mathrm{p} \leq .01\right) . \mathrm{B}=, 526$ value for local style indicates the extend of the increase for hypothetico-creativity corresponding the 1 unit increase for legislative style. Similarly B=,329 value for global style indicates the extend of the increase for hypothetico-creativity corresponding the 1 unit increase for legislative style. Local and global styles explain \%12 of total variance. Local and global styles are thought to be stronges predictor of hypotheticocreativity, in terms of $\beta$ constant and t values. In this context, local and global learning styles are thought to be a significant and meaningful predictor for hypothetico-creative reasoning skills.

Question 4: What is the relationship between the dimension of "scopes" of learning styles (perception of their learning styles) and hypothetico-creative reasoning skills (perception of their reasoning skills)? 
Durbin-Watson value which is supposed to be between values 1 and 3 is found to be 1.756 From regression analysis, $F=29,947$, p=.000 values was found indicating that they have predicting feauteres.

Tablo 9: Descriptive statistics and pearson correlation analysis for the dimension of "scopes" of learning styles and hypothetico-creative reasoning skills

\begin{tabular}{|c|c|c|c|c|c|c|c|c|c|c|}
\hline & & \multirow[t]{2}{*}{$\mathbf{N}$} & \multirow[t]{2}{*}{$\mathbf{X}$} & \multirow{2}{*}{$\begin{array}{c}\text { Std. } \\
\text { Deviati } \\
\text { on } \\
\end{array}$} & \multicolumn{2}{|c|}{$\frac{\text { H.Y. Akıl }}{\text { Yürütme }}$} & \multicolumn{2}{|c|}{ Internal } & \multicolumn{2}{|c|}{ External } \\
\hline & & & & & $\mathbf{R}$ & $\mathbf{p}$ & $\mathbf{R}$ & $\mathbf{P}$ & $\mathbf{R}$ & $\mathbf{P}$ \\
\hline H.Creativ & & 383 & $\begin{array}{r}80,94 \\
26\end{array}$ & $\begin{array}{r}13,652 \\
45 \\
\end{array}$ & - & - & ,301 & .000 & ,157 & .001 \\
\hline $\begin{array}{l}\text { Scopes in } \\
\text { Thinking }\end{array}$ & Internal & 383 & $\begin{array}{r}34,54 \\
05\end{array}$ & $\begin{array}{r}9,8925 \\
0\end{array}$ & ,301 & , 000 & - & - &,- 175 & .000 \\
\hline Styles & External & 383 & $\begin{array}{r}37,20 \\
37 \\
\end{array}$ & $\begin{array}{r}9,2289 \\
3 \\
\end{array}$ & ,157 & ,001 &, 175 & .000 & - & - \\
\hline
\end{tabular}

Table 10: Linear regression analysis for the dimension of "scopes" of learning styles and hypothetico-creative reasoning skills

\begin{tabular}{lccccc}
\hline Constant & B & $\begin{array}{c}\text { Standart } \\
\text { Deviation }\end{array}$ & B & T & P \\
\hline Constant & 52,854 & 3,875 & - & 13,640 &, 000 \\
Internal &, 468 &, 067 &, 339 & 7,002 &, 000 \\
External &, 321 &, 072 &, 217 & 4,474 &, 000 \\
\hline
\end{tabular}

As seen results inTable 9-10, linear regression analysis for the dimension of scopes of learning styles and hypothetico-creative reasoning skills indicates that there is a significant and meeaningful level of relationship between anarchic and hierarchic dimensions of function and hypothetico creativity $\left(\mathrm{R}=.369, \mathrm{R}^{2}=.136, \mathrm{p} \leq .01\right) . \mathrm{B}=, 468$ value for internal style indicates the extend of the increase for hypothetico-creativity corresponding the 1 unit increase for legislative style. Similarly $\mathrm{B}=, 321$ value for external style indicates the extend of the increase for hypothetico-creativity corresponding the 1 unit increase for legislative style. Internal and external styles explain $\% 12,7$ of total variance. Internal and external styles are thought to be stronges predictor of hypothetico-creativity, in terms of $\beta$ constant and $t$ values. In this context, internal and external learning styles are thought to be a significant and meaningful predictor for hypothetico-creative reasoning skills. 
Question 5:What is the relationship between the dimension of leanings of learning styles (perception of their learning styles) and hypothetico-creative reasoning skills (perception of their reasoning skills)?

Table 11: Descriptive statistics and pearson correlation analysis for the dimension of "leanings" of learning styles and hypothetico-creative reasoning skills

\begin{tabular}{|c|c|c|c|c|c|c|c|c|c|c|}
\hline & & \multirow[t]{2}{*}{$\mathbf{N}$} & \multirow[t]{2}{*}{$\mathbf{X}$} & \multirow{2}{*}{\begin{tabular}{|c} 
Std. \\
Devviati \\
on
\end{tabular}} & \multicolumn{2}{|c|}{$\underset{\text { Creative }}{\text { H.Y. }}$} & \multicolumn{2}{|c|}{ Liberal } & \multicolumn{2}{|c|}{ Conservative } \\
\hline & & & & & $\mathbf{R}$ & $\mathbf{p}$ & $\mathbf{R}$ & $\mathbf{P}$ & $\mathbf{R}$ & $\mathbf{P}$ \\
\hline H.Creaitivit & & 383 & $\begin{array}{r}80,94 \\
26\end{array}$ & $\begin{array}{r}13,6524 \\
5\end{array}$ & - & - &, 510 & .000 &,- 070 & .087 \\
\hline $\begin{array}{l}\text { The } \\
\text { Leanings in }\end{array}$ & Liberal & 383 & $\begin{array}{r}40,12 \\
53\end{array}$ & 8,25256 & ,510 & ,000 & - & - &,- 104 & .021 \\
\hline $\begin{array}{l}\text { Thinkings } \\
\text { Styles }\end{array}$ & $\begin{array}{c}\text { Conservat } \\
\text { ive }\end{array}$ & 383 & $\begin{array}{r}32,06 \\
53\end{array}$ & 9,00689 &,- 070 & ,087 & $\begin{array}{c}- \\
, 104\end{array}$ & .021 & - & - \\
\hline
\end{tabular}

Durbin-Watson value which is supposed to be between values 1 and 3 is found to be 1.766 From regression analysis, $F=66,792$, p=.000 values was found indicating that they have predicting featuresAs seen results inTable 13-14, linear regression analysis for the dimension of "leanings" of learning styles and hypothetico-creative reasoning skills indicates that there is a significant and meeaningful level of relationship between liberal dimensions of function and hypothetico creativity $\left(\mathrm{R}=.510, \mathrm{R}^{2}=.26, \mathrm{p} \leq .01\right) . \mathrm{B}=, 840$ value for internal style indicates the extend of the increase for hypotheticocreativity corresponding the 1 unit increase for liberal style. Liberal and conservative styles explain \%25,6 of total variance.

Table 12: Linear regression analysis for the dimension of "leanings" of learning styles and hypothetico-creative reasoning skills

\begin{tabular}{cccccc}
\hline Variable & B & $\begin{array}{c}\text { Standart } \\
\text { Deviation }\end{array}$ & B & T & P \\
\hline Constant & 48,054 & 3,873 & - & 12,407 &, 000 \\
Liberal &, 840 &, 073 &, 508 & 11,449 &, 000 \\
Conservative &,- 026 &, 067 &,- 017 &,- 385 &, 701 \\
\hline
\end{tabular}

Liberal style is thought to be stronges predictor of hypothetico-creativity, in terms of $\beta$ constant and $t$ values. In this context, liberal style is thought to be a significant and meaningful predictor for hypothetico-creative reasoning skills. 


\section{Results And Disscussion}

Legislative and judicial learning styles are thought to be a significant and meaningful predictor for hypothetico-creative reasoning skills whereas no siginificant relationship can be found between executive styles and hypothetico-creativity. Function category is mainly related with creativity and planning. Legislative individuals are more prone to set their own rules. Executive individuals are inclined to to be given more structure and guidance or even told what to do. People with a judicial style prefer to evaluate and judge things and especially the work of others. People with judiciall style are more likely to engage in higher order thinking activities such as analysis, evaluation in Bloom taxanomy. Evaluation, analysis, synthesis of something both depend on left brain because of logic and the evidence as the form of data, information and knowledge and also right brain functions because of the wisdom and ideas that gives the individuals' own genre. Hence legislative and judicial styles are more related with right brain function and creativity whereas executive style is in relation with left brain functions like planning. However judicial typle learnes can also be evaluated in the midle of executive and legislative learning styles becuse it both inludes the characteristics of progress (right prain) and order (left brain)Similar results for anarchic and hierarchic global, external and liberal styles can be interpreted in the context of creativity.The hierarchic person has a hierarchy of goals, recognizes the need to view problems from a number of angles so as to set priorities correctly.Anarchic people take what seems like a random approach to problems; they tend to reject systems. Global people, prefer to focus on the forest, sometimes at the expense of the trees.People with an external style are inclined to be more extroverted, people-oriented, outgoing, socially more sensitive, and interpersonally more aware.Individuals with a liberal style like to go beyond existing rules and procedures and seek to maximize change. Hence anarchic and hierarchic global, external and liberal styles can be attributed to the right brain. As opposed the characteristics of right brain, similar categorization can be done for monarchic, oligarchic, local, internal, conservative thinking styles in terms of the attributes of left brain(Sternberg, 1999: 27-74;Zhu and Zhang, 2011:363; Baştuğ, Çelik,2014). As seen figure 8 in the dimenson of functions students are more likely to perceive themselves as creative than rational. However they perceive themselves as individuals having local and internal thinking styles which can be attributed to the characteristics of left brain.

Zhang (2002:339-342) pointed out analytic mode of thinking is closely related with executive, local, and conservative in their thinking styles, 
whereas holistic mode of thinking is more related with legislative, judicial, global, and liberal in their thinking styles. He also pointed out that executive, local, and conservative in their thinking styles became more analytic in processing information, whereas legislative, judicial, global, and liberal thinking styles are more holistic in processing information.

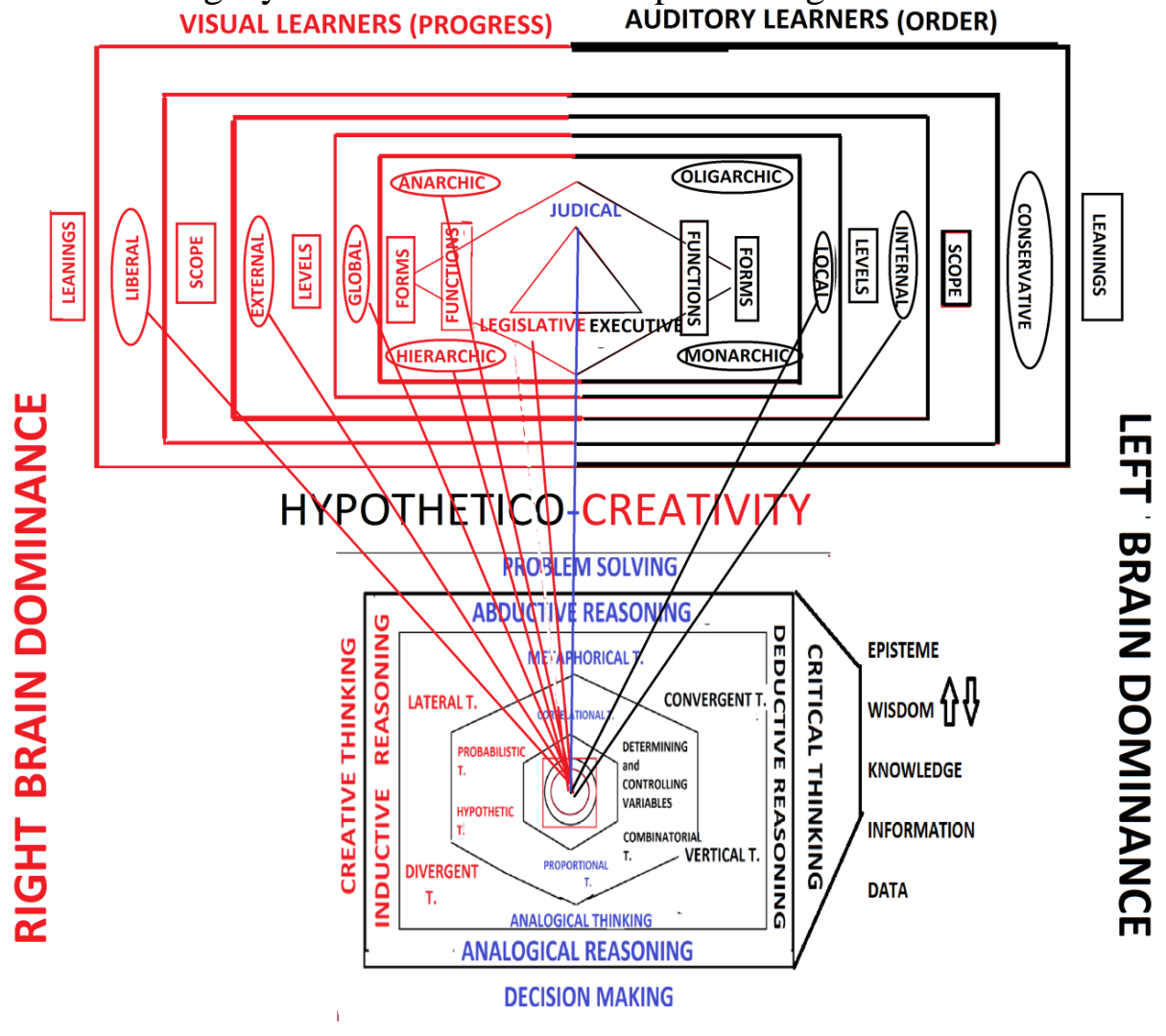

\section{WHOLE BRAIN DOMINANCE}

Figure 8. The relationship between learning styles and hypothetico-creativity indicates that students are more likely to use right brain functions in relation the characteristics of learning styles (Modified from Duran,2014).

Kim and Michael (1995) found that irrespective of gender, students regarded as displaying a thinking style inclinations assumed to be related with right-brain dominance are more prone to earn higher scores on creativity measures than the students classified as displaying a learning and thinking style preference hypothesized to correspond to either a left-brain dominance or an integrated-brain dominance. Students who are engaged in extracurricular experience scored significantly higher onthe legislative, hierarchical, and liberal thinking styles, whereas students who reported less extracurricular experience are more prone to scored significantly higher on 
the executive, local, and conservative thinking styles (Zhang, 1999). Buluş (2005) found that thestudent teachers generally are in a tendency to use more the first type thinking styles hence can be cateogrized as creative. Balkıs andIşıker (2005:289) found that artisticpersonality type is significantly and positive correlated with legislative thinking and conventional personality typeand conservative thinking style are significantly and positively correlated. However their findings don't imply one to one correspondance in the contect of the general characteristics of left and right brain. It is supposed that the sample chosen this study reflects integrative mode of thinking (originally whole-brained dominance). Eraslan (2014) found that executive, anarchic and local thinking styles are decreasing creativity which is compatible with its general attributes as belonging to left brain except the attributes of anarchist style. Zhu ve Zhang (2011) found that that art students scored higher than students in social sciences in legislative and internal thinking styles. Zhang and Sternberg (1998) observed that executive, local, internal, and conservative Chinese students scored higher than other university students in academic achievement.Hence literature support the idea the right and left brain distinction in the context of thinking styles but there are som contrary findings such as Eraslan (2014) saying that anarchic thinking style is decreasing creativity.

As seen in the finding and Figure 8 students perceive themselves creative in terms of thinking styles belonging to the attributes of right brain. However creativity isn't related just with one or more dimension thinking styles. As pointed out by Zhang (2002) if the individuals use thinking styles better, the more creative they are. Lubart (1994) and Sternberg and Lubart (1995) stressed the importance of certain personality attributes such as a person's willingness to take sensible risks and willingness to overcome obstacles for creativity. Duran (2015) also pointed out the importance of affective side of human intellect in the context of the hierarchy of needs, drives, motives, incentives, intention (commitment/perseverance), passion. Hence eros as a passion is an important factor for the commitment and perseverance of creative work. Furthermore brain can be conceived as a parallel processor and dynamic hole and manifest its attiributes so differently that might suprise us as opposed to static definitions of those attributes.It should be also noted that creativity has social, individual and culutral domains. Hence creativity is not the result of thinking styles but maybe thinking styles are the disposition of creative mind or attitudes. In the context of DIKWE and hypothetico creativity model, episteme (ideas/pinions) based on pure imagination is thought to be fantasy, episteme lack of knowledge, wisdom 
or enough information is supposed to lead absurdity and episteme without any coherent rules can be idendified with nonsensical (Duran, 2015). Hence as seen in figure 8 , students are more prone to use their right brains, that is lateralization of hepispheric specialization is thought to be in right side. It implies that they perceived themselves creative but this creativity is not rational or hypothetico-creative in this context.

Finally different inventories and scales can be used in the context of the characteristics of righ and left brain and this researches can conducted based on different models, designs ans samples. Furthermore, educational activities should be arranged so as to improve both sides of students hemispheres rather than restricting them to use one side, in other words playing the foofball in just one side of stadium.

\section{References and notes:}

Acat, M.B. Tüken, G. and Karadağ, E. (2010). Scientific Epistemological Veliefs Survey: Translation and Cultural Adaptation Ease of Use, Validity, and Reliability, Turkish Science Education, 7(4), 67-89.

Balkıs M. and Işıker, G. B. (2005). The Relatioship Between Thinking Styles And Personality Types, Social Behavior and Personality and International Journal. 33(3): 283-294.

Baştuğ, Ö. Y. Ö. and Çelik, B. (2014). Thinking Styles of Teachers, Principals and Inspectors, Educational Research and Review, 9(21),1173-1184.

Buluş, M. (2005).The Investigation of the Thinking Styles Profile of Students in the Department of Elementary Education, Ege University Journal of Education, (6) $1,1-24$.

Büyüköztürk, Ş., Çakmak E.K., Akgün Ö.E., Karadeniz Ş. and Demirel F. (2008). Scientific Research Methods, Ankara: Pegem Akademi Publishing.

Cassidy, S. (2004). Learning Styles: An Overview of Theories, Models, and Measures, Educational Psychology, 24 (4), 419-442.

Chan, D. W. (2002). Intellectual Styles of Exceptional Learners, Handbook of Intellectual Styles Preferences in Cognition, Learning, and Thinking(Edts. Zhang, L. F., Sternberg, R. J., Rayner, S.) New York: Springer Publishing.

Duran, V. (2014) The Investigation of the hypothetic-creative reasoning skills of the teacher trainees in terms of their scientific epistemological beliefs, learning styles and their demographic characteristics, Master's Thesis, Muğla Sitkı Koçman University, Muğla.

Duran, V. (2015). The Development of Hypothetico-Creativite Reasoning Skills Inventory, Presented in International Congress on Education for Future: Issues and Challanges, (ICEFIC),Abstract Book 227-228, AnkaraUniversity Publishing, https://www.academia.edu/19775202/The Development of HypotheticoCreative_Reasoning_Skills_Inventory (Accessed, 09.07.16)

Duran, V. (2016). Mantıksal Muhakeme Becerileri Düşünce Deneyleri ve Yaratıcılık, Altıncı Mantık Çalıştayı, Artvin (Not Published Yet). https://www.academia.edu/25783418/MANTIKSAL_MUHAKEME_BECER\%C4 


\section{\%B0LER\%C4\%B0_D\%C3\%9C\%C5\%9E\%C3\%9CNCE_DENEYLER\%C4\%B0 VE_YARATICILIK (Accessed, 09.07.16)}

Eraslan, M. (2014). The Analysis of the Thinking Styles and Creativity of the Sports Students Studying In the Different Fields of University, Educational Research and Reviews, 9 (20),866-871.

Fer, S. (2005). Validity and Reliability of the Thinking Styles Inventory. Educatıonal Sclences: Theory\&Practice, 5 (2), 433-461.

Fordham, F. (2001).An Introduction to Jung's Psychology, İstanbul: Say Publishing.

Gardner, H. (1993).Creating Minds. New York: Basic Books.

Gardner, H. (2007).Five Minds for Future, Boston: Harvard Business School Press.

Gelen, I. (2014).Evaluating Secondary School Students'Level of Five Mind Areas in Terms of Some Variables, Educational Research and Reviews, 10 (2), 119-129.

Gregorc, A. F. (1979). Learning/Teaching Styles: Potent Forces Behind Them. Educational Leadership, 36(4), 234-236.

Herrmann, N. (2002). The Whole Brain Business Book, Second Edition: Unlocking the Power of Whole Brain Thinking in Organizations, Teams, and Individuals, İstanbul: Hayat Publishing.

Kim, J. and Michael, W.B. (1995). The Relationship Of Creativity Measures To School Achievement And Preferred Learning And Thinking Style İn A Sample Of Korean HighSchool Students. Educational and Psychological Measurement, 55, 60-74.

Kolb, A. Kolb, (2005). The Kolb Learning Style Inventory_-Version 3.12005 Technical Specifications, Experience Based Learning Systems, Inc., Hay Group, http://learningfromexperience.com/media/2010/08/tech_spec_lsi.pdf , (Accessed, 09.07.16)

Lawson, A.E. (1995). Science Teaching and Development of Thinking. Belmont, New York: , CL: Wadsword Publishing Company.

Lubart, T.I. (1994). Creativity. In R.J. Sternberg (Ed.), Thinking and problem solving (pp. 290-332). San Diego, CA: Academic Press.

Moseley, D., Baumfield, V., Elliott, J., Gregson, M., Higgins, S., Miller, J. and Newton, D. (2005). Frames for Thinking A Handbook for Teaching and Thinking, New York: Cambridge University Press.

Moseley, D., Baumfield,V., Elliott, J., Gregson, M., Higgins,S., Miller, J. and Newton, D. (2005).Frames for Thinking A Handbook for Teaching and Thinking, CambridgeUniversity Press, New York.

Nielsen, T. (2002). A Historical Review of the Styles Literature, Handbook of Intellectual Styles Preferences in Cognition, Learning, and Thinking (Edts. Zhang, L. F., Sternberg, R. J., Rayner, S.) Springer Publishing Company, New York.

Ornstein, R. (1977). The Psychology of Consciousness, New York: Harcourt Brace.

Rayner, S., Roodenburg, J., and Roodenburg, E. (2002). Understanding an Integrated Theory of Intellectual Styles: Moving From Models to Measures and Meaning, Handbook of Intellectual Styles Preferences in Cognition, Learning, and Thinking (Edts. Zhang, L. F., Sternberg, R. J., Rayner, S.) New York: Springer Publishing Company.

Riding, R. J., and Cheema, I. (1991). Cognitive styles - An overview and integration. Educational Psychology, 11(3 \& 4), 193-215.

Sadler Smith, E. (2002). Metacognition and Styles, Handbook of Intellectual Styles Preferences in Cognition, Learning, and Thinking (Edts. Zhang, L. F., Sternberg, R. J., Rayner, S.) New York: Springer Publishing Company. 
Schleifer, L. L. F.,\& Dull, R. B. (2009). Metacognition and performance in accounting classrooms. Issues in Accounting Education, 24(3), 339-367.

Sharp, D. (1987).Personality Types, Jungs Model of Typology, Canada: Inner City Books.

Sizak, S. (2012). Less than nothing : Hegel and the shadow of dialectical materialism, New York:Verso Books.

Sousa, D. A. (2003). How the Gifted Brain Learns. Thousand Oaks, CA: Corwin Press.

Sousa, D. A. (2006). How the Brain Learns (3rd ed.). Thousand Oaks, CA: Corwin Press.

Sousa, D. A. (2007). How the Special Needs Brain Learns (2nd ed.). Thousand Oaks, CA: Corwin Press.

Sperry, R.W. (1968). Hemisphere Disconnection and Unity in Conscious Awareness, American Psychologist, 23(10), 723-33.

Sternberg, R. J ve Zhang, L.F. (2005). Styles of Thinking as a Basis of Differentiated Instruction, Theory Into Practice, 44 (3), 245-253.

Sternberg, R. J. (1988). Mental Self-government: A Theory of İntellectual Styles and Their Development. Human Development, 31(4), 197-224.

Sternberg, R. J. (1999).Thinking Styles, Cambirdge: Cambridge University Press.

Sternberg, R. J. and Wagner, R.K. (1992) Thinking Styles Inventory, Unpublished Test, Yale University.

Sternberg, R. J., and Grigorenko, E. L. (1997). Are cognitive styles still in style? American Psychologist, 52(7), 700-712.

Sternberg, R. J., and Grigorenko, E. L. (2001). A Capsule History and Research On Styles. In R. J. Sternberg \& L.-F. Zhang (Eds.), Perspectives on thinking, learning and cognitive styles (pp. 1-22). London: Lawrence Erlbaum Associates Publishers.

Sternberg, R.J.,and Lubart, T.I. (1995). Defying The Crowd: Cultivating Creativity In a Culture of Conformity. New York: Free Press.

Sternberg, R. J.,and Zhang, L. F. (Eds.) (2001). Perspectives On Thinking, Learning, and Cognitive Styles. Mahwah, NJ: Lawrence Erlbaum Associates Publishers.

Witkin, H.A. (1973). The Role Of Cognitive Style in Academic Performance and in Teacherstudent Relations. Paper Presented at a Symposium on Cognitive Styles,Creativity and Higher Education. Sponsored By The Graduate Record Examination Board, Montreal, Canada. Princeton, N.J.:Educational Testing Service, Research Bulletin, 73 - 11. http://files.eric.ed.gov/fulltext/ED083248.pdf , (Accessed, 09.07.16)

Yöney, H. (2011). Hemispheric Specialization and Psychopathology, Klinik Psikofarmakoloji Bülteni, Cilt: 11(1).53-59.

Zhang, L. and Sternberg, R. (1998). Thinking Styles, Abilities and Academic Achievement among Hong Kong University Students. Educational Research Journal, 13, 41-62.

Zhang, L. F (2002). Thinking Styles and Models of Thinking: Implications for Education for Education and Research, J. Psychology. 136 (3),245-261.

Zhang, L. F. (2000). Relationship between ThinkingStyles Inventory and Study Process Questionnaire. Personality and Individual Differences, 29, 841-856.

Zhang, L. F., Sternberg, R. J. (2000). Are Learning Approaches And Thinking Styles Related? A Study İn Two Chinese Populations. The Journal of Psychology, 134, 469-489.

Zhang, L. F., Sternberg, R. J., Rayner, S. (2002). Culture and Intellectual Styles Milestones, and Agenda, Handbook of Intellectual Styles Preferences inCognition, Learning, and Thinking(Edts. Zhang,L.F., Sternberg,R. J., Rayner, S.) New York: Springer Publishing Company. 
Zhang, L. F., Sternberg, R. J., Rayner, S. (2002). Intellectual Styles: Challenges, Milestones, and Agenda, Handbook of Intellectual Styles Preferences in Cognition, Learning, and Thinking(Edts. Zhang, L. F., Sternberg, R. J., Rayner, S.) New York: Springer Publishing Company.

Zhang, L. F., and Sternberg, R. J. (2005). A threefold model of intellectual styles.Educational Psychology Review, 17(1), 1-53.

Zhang, L.F. (1999). Further Cross-Cultural Validation of The Theory of Mental SelfGovernment. Journal of Psychology, 133 (2), 165-181.

Zhang, L.F. (2000). Are Thinking Stylesand Personality Types Related? Educational Psychology: An International Journal of Experimental Educational Psychology, 20(3), 271-283, DOI: 10.1080/713663742.

Zhu, C. Ve Zhang, L. F. (2011). Thinking Styles And Conceptions Of Creativity Among University Students, Educational Psychology, 31(3), 361-375.

Zull, J. E. (2002). The art of Changing the Brain: Enriching Teaching by Exploring the Biology of Learning. Sterling, Virginia: Stylus Publishing.

\title{
Summary
}

\section{Invetigation of Hypothetico-Creative Reasoning Skills of Teacher Trainees in Terms of Their Thinking Styles}

\author{
İsmail Gelen \\ Ondokuz Mayıs University,Turkey \\ Volkan Duran \\ Gazi University,Turkey \\ Bayram Özer \\ Ondokuz Mayıs University,Turkey
}

Thinking styles more boradly intellectual styles refers to people's partly fixed, relatively stable and innate preferences about information processing and handling with the tasks that they may confront (Zhang \& Sternberg, 2005). Sternberg's (1988) introduced of the theory of mental self-government, where intellectual style specifies 13 thinking styles that fall along five dimensions of mental self-government: (a) functions, (b) forms, (c) levels, (d) scopes, and (e) leanings of government as applied to individuals (Zhang, Sternberg, Rayner, 2002: 14).Hypothetico-Creative reasoning model developed by Duran (2014) can be defined skills including logical and creative thinking skills in 12 dimensions. This study, is a descriptive study based on, relational screening model among the screening models. The purpose of this study is to investigate the relationship between learning styles proposed by Sternberg (1988) and hypothetico-creative reasoning skills proposed by Duran (2014) in the context of the characteristics of left an right brains or thinking modes emphasized by Zhang (2002). The population consists of all the second grade students $(\mathrm{N}=383)$ in those 
departments in the education period 2015-2016 in English Teaching Department, Preschool Education Department, Department of Elementary Education, The Department of Computer Education and Instruction, The Department of Psychological Counseling And Guidance. It was found thatstudents are more prone to use their right brains, that is lateralization of hepispheric specialization is thought to be in right side. Hence students perceive themselves to use Type I thinking, holistic mode of thinking styles indicating that they use right brain hence perceive themselves to be more holistic, creative and experiantial learners.

Keywords: Thinking Styles, Hypothetico-Creative Reasoning Skills,Hemispheric Specialization, Lateralization 